\title{
Drying kinetics and impact on the volatile compounds of ogi using response surface modelling
}

\author{
1," Bolaji O.T., ${ }^{1}$ Apotiola, Z.O., ${ }^{1}$ Ojo, T.I., ${ }^{2}$ Akoro S.M. and ${ }^{1}$ Ogunsola, A.O. \\ ${ }^{1}$ Department of Food Technology Lagos State Polytechnic, Ikorodu, Lagos Nigeria \\ ${ }^{2}$ Department of Chemical Science, Lagos State Polytechnic, Ikorodu, Lagos Nigeria
}

\begin{abstract}
Article history:
Received: 29 March 2019

Received in revised form: 11

October 2019

Accepted: 15 October 2019

Available Online: 30 October 2019
\end{abstract}

Keywords:

Ogi,

Volatile compounds (VOCs), Gas chromatography (GC), Drying operation,

Aroma

DOI:

https://doi.org/10.26656/fr.2017.4(2).287

\begin{abstract}
This research aimed at studying the drying kinetic and impact on the volatile compounds of ogi slurry dried within designed drying condition (Drying temperature: 40,50 and $60^{\circ} \mathrm{C}$ and drying time: 8,10 and $12 \mathrm{hrs}$ ) using a central composite rotatable experimental design with two factors and five levels (-1.4142, -1, 0, 1 and 1.4142). Gas Chromatography-Mass Spectrometry (GC-MS) was used to detect volatile compounds of the dried ogi. The results revealed that the moisture content and moisture ratio of the samples decreased continually with the increase in drying temperature and time. The drying rate of the operation also decreased with increased drying time. The retention time of thirty-five volatile compounds detected in fresh ogi, dried ogi and dried maize grains ranged from 9.67 to 26.96 mins. There was a significant difference $(p<0.05)$ between the concentration of volatile compounds detected in wet ogi compared with dried ogi. More than twenty volatile compounds identified in dried ogi and dried maize grains significantly $(p<0.05)$ reduced up to $95-99 \%$ when compared with fresh wet ogi. The first and second principal components for dried ogi had variances of eigenvalue 32.04 and 1.92, respectively. The study revealed and established the challenges of retaining important volatile compounds responsible for aroma flavour in dried ogi product, most especially with the use of a cabinet dryer.
\end{abstract}

\section{Introduction}

The relevance of drying operation in food processes is particularly mostly applied to food preservation, food product development, distribution and transportation (Hawlader et al., 2006; Hadrich et al., 2008). The reduced water activity during drying of food materials helps prevent undesirable reactions, deterioration and spoilage. By this, the Shelf-life of food material is increased, transportation and distribution of food are made easy as a result of volume reduction (Moraga et al., 2004; Hawlader et al., 2006; Shi et al., 2008; Bolaji, Oyewo and Adepoju, 2014). However, physical changes, chemical reactions and alteration in some sensory characteristics were reported by some researchers as a possibility during this process (Díaz-Maroto et al., 2003; Zielinska and Michalska 2016; Huang et al., 2016; Bolaji et al., 2017a). The drying temperature, humidity, flow direction and intensity (flow rate) of the drying air, area of the exposed surface of the food particle, composition and structure of the food have been identified as important factors in the drying process (Hawlader et al., 2006; Hadrich et al., 2008). These are capable of determining the efficiency of the process and the quality of the product.

In view of the importance of ogi and the derived food products, an increase in working class mothers and demand for ogi in the urban region of most west Africa countries, large scale production is appearing indispensable. Ogi slurry is not shelf-stable independently without some necessary action taken. Apart from the traditional method of daily decantation of water, refrigeration is often applied. Unfortunately, this requires a constant power supply which is not always available. This makes dried ogi with potential shelf-life stability a needed option. In the past, drying of ogi was attempted and recommended to increase shelf life (Bolaji, Oyewo and Adepoju, 2014; Bolaji, Akindele and Aina, 2014; Bolaji et al., 2015). However, based on the findings of some researchers, the flavour, aroma and taste usually impacted by the presence of volatile compounds may be affected by dehydration process (Zielinska and Michalska 2016; Huang et al., 2016). Most of the drying of ogi slurry in the recent times either for commercial or research purposes has always been cabinet and oven drying methods (Bolaji, Akindele and 
Aina, 2014, Bolaji et al., 2015). The impact of the drying process and method on the volatile compounds believed to be responsible for the acceptable taste, aroma and flavour need to be investigated. The findings will be useful information needed in handling the ogi slurry during the drying process, help to select possible processing conditions that are capable of aiding conservation of these parameters and may help where possible in the development of ogi flavour from principal volatile compounds.

\section{Materials and methods}

Thirteen kilograms $(13 \mathrm{~kg})$ of maize grains were divided into equal parts of $1 \mathrm{~kg}$ each after foreign materials were carefully removed and were soaked for 24 hrs, wet milled and sieved with $212 \mu \mathrm{m}$ sieves. (Bolaji, Adenuga-Ogunji and Abegunde, 2017). These were allowed to ferment for $24 \mathrm{hrs}$. The wet ogi samples were dried at varying combination of drying temperature (40, 50 and $\left.60^{\circ} \mathrm{C}\right)$ and time $(8,10$ and $12 \mathrm{hrs})$ using a central composite rotatable experimental design by design expert software with two factors and five levels (-1.4142, $-1,0,1$ and 1.4142) as shown in Table 1. The drying process was achieved with the aid of locally fabricated cabinet drier. The drying kinetics was evaluated and the volatile compounds of the dried ogi with the use of Gas Chromatography-Mass Spectrometry (GC-MS) were determined.

\subsection{Experimental design and modelling for optimization}

Response surface modeling (RSM) comprising of central composite design with two factors and five levels were used as shown in Table 1. A second-order polynomial equation was fitted to determine the relationship between dependent variables and independent variables. The model proposed for the response (Yi) was:

$$
\mathrm{Yi}=\mathrm{b}_{0}+\mathrm{b}_{1} \mathrm{X}_{1}+\mathrm{b}_{2} \mathrm{X}_{2}+\mathrm{b}_{11} \mathrm{X}_{1}{ }^{2}+\mathrm{b}_{22} \mathrm{X}_{2}{ }^{2}+\mathrm{b}_{12} \mathrm{X}_{1} \mathrm{X}_{2}
$$

Where $\mathrm{X}_{1}$ and $\mathrm{X}_{2}$ are drying temperatures $\left({ }^{\circ} \mathrm{C}\right)$ and drying time (hrs) respectively; $\mathrm{b}_{0}$ is the value of the fitted response at the centre point of the design; and $\mathrm{Yi}$ is the predicted response. The regression coefficient for the linear, quadratic and interaction are represented by $b_{1}-b_{2}$, $b_{11}-b_{22}$ and $b_{12}$, respectively. The significance of regression coefficients was accessed by $p$-value at 0.05 significance levels.

Table 1. Coded values of the independent variables

\begin{tabular}{lccccc}
\hline & $-\alpha$ & -1 & 0 & 1 & $+\alpha$ \\
\hline $\mathrm{X}_{1}$ (drying temperature) & 42.93 & 40 & 50 & 60 & 57.07 \\
$\mathrm{X}_{2}$ (drying time) & 8.59 & 10 & 12 & 16 & 11.41 \\
\hline
\end{tabular}

$\alpha=1.4142 . X_{1}$, drying temperature; $X_{2}$, drying time.
The moisture content determination of wet and dried ogi was in accordance with AOAC (1990). Drying experiments were expressed in dimensionless form as moisture ratios, MR as shown in equation (2):

$$
\mathrm{MR}=\frac{\mathrm{M}-\mathrm{M}_{\mathrm{e}}}{\mathrm{M}_{\mathrm{i}}-\mathrm{M}_{\mathrm{e}}}=\exp (-\mathrm{kt})
$$

Where $\mathrm{M}$ is the moisture content at any time; $\mathrm{M}_{\mathrm{i}}$ is the initial moisture content; and $\mathrm{M}_{\mathrm{e}}$ is the equilibrium moisture content (Aghbashlo et al., 2009; Mirzaee et al., 2009).

\subsection{Determination of volatile compounds}

Volatile compounds determination of wet and dried ogi was achieved using GC-MS method. The extraction of the volatile compound was determined by measuring 5 $\mathrm{g}$ of each sample, mixed with $20 \mathrm{~mL}$ of distilled water, filtered and centrifuged at 10,000 x $g$ for 30 mins. All the volatile compounds of wet and dried ogi and dried maize grain were analysed by using the Agilent Technologies 6890 gas chromatography HP chemstation Rev.A0901 (1206). The Headspace extraction of ogi volatile compounds was within 30 mins at a temperature of $60^{\circ} \mathrm{C}$ followed by GC separation elaborated with column oven initial temperature at $35^{\circ} \mathrm{C}$ at the rate of $5^{\circ} \mathrm{C} / \mathrm{min}$ to reach $300^{\circ} \mathrm{C}$. Identification of the compounds was by $\mathrm{GC}$ retention time against standards.

\section{Results and discussion}

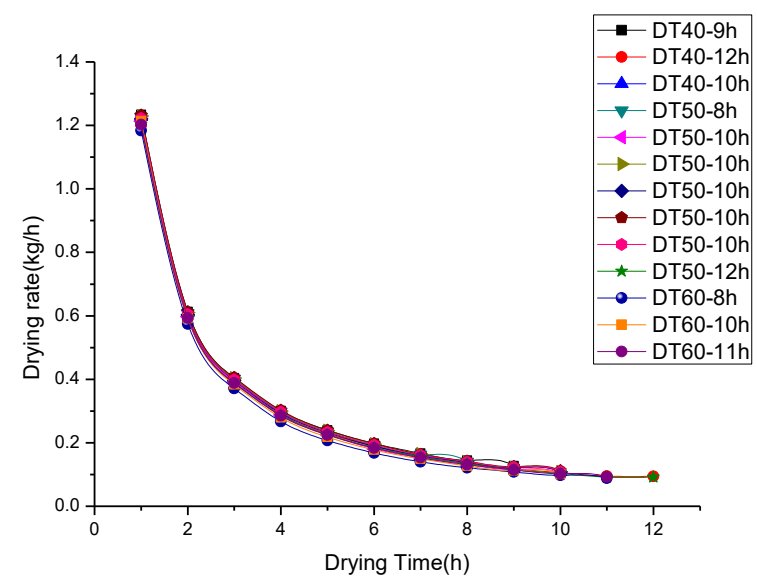

Figure 1. Drying rate of ogi slurry at varying drying condition

The rate of moisture removal from wet ogi with initial average moisture content of $48.31 \%$ during drying process of ogi was affected by the surface area, pore spaces and thermal properties of the ogi slurry as reported by some researchers (Moraga et al., 2004; Hawlader et al., 2006; Shi et al., 2008; Bolaji, Akindele and Aina, 2014; Bolaji et al., 2015). As shown in Figure 1 the drying rate continuously decreased with decrease and increase in moisture content and drying time, respectively. This was consistent with the findings of 
some researchers (Doymaz, 2005; Bolaji, Akindele and Aina, 2014). According to Zielinska and Michalska (2016), the drying operation may have caused some chemical alterations in ogi during the drying operation.

\subsection{Estimation of effective moisture diffusivities}

The effective diffusivities of the drying process of ogi were estimated by the method reported for drying characteristics of biological products in falling rate period using Fick's diffusion equation (Perea-Flores et al., 2012) as shown in equation (3):

$$
\text { MR }=\frac{8}{\pi^{2}} \sum_{\mathrm{n}=1}^{\infty} \frac{1}{\mathrm{n}^{2}} \exp \left[-\mathrm{n}^{2} \frac{\mathrm{m}^{2} \mathrm{D}_{\text {eff }} t}{r^{2}}\right]
$$

Where MR is the moisture ratio; $D_{\text {eff }}$ is the effective moisture diffusivity $\left(\mathrm{m}^{2} / \mathrm{s}\right) ; r$ is the equivalent radius $(\mathrm{m})$ and $t$ is the time (s). A logarithmic form is as shown in Equation (4). The effective moisture diffusivity was calculated from the slope of a straight line obtained from the plot of $\ln (\mathrm{MR})$ and drying time (Perea-Flores et al., 2012).

$$
\ln \mathrm{MR}=\ln \frac{8}{\pi^{2}}-\left(\frac{\pi}{r}\right)^{2} \mathrm{D}_{\text {eff }} t
$$

The effective moisture diffusivity was estimated by using the method of slopes. From Equation (3), a plot of $\ln (\mathrm{MR})$ versus drying time gave a straight line and the slope was determined using equation (5):

$$
\text { Slope }=\frac{\pi^{2} \mathrm{D}_{\text {eff }}}{r^{2}}
$$

Table 2. Effective moisture diffusivity of ogi at experimental drying condition

\begin{tabular}{ccc}
\hline Drying conditions & $\begin{array}{c}\text { Final moisture } \\
\text { content (\%) }\end{array}$ & Effective diffusivity \\
\hline $40^{\circ} \mathrm{C}-9 \mathrm{hrs}$ & 30.96 & -64 \\
$40^{\circ} \mathrm{C}-12 \mathrm{hrs}$ & 8.98 & -1.3 \\
$40^{\circ} \mathrm{C}-10 \mathrm{hrs}$ & 20.52 & -1.3 \\
$50^{\circ} \mathrm{C}-8 \mathrm{hrs}$ & 26.96 & -99 \\
$50^{\circ} \mathrm{C}-10 \mathrm{hrs}$ & 7.86 & -2.2 \\
$50^{\circ} \mathrm{C}-10 \mathrm{hrs}$ & 18.6 & -1.1 \\
$50^{\circ} \mathrm{C}-10 \mathrm{hrs}$ & 17.72 & -1.1 \\
$50^{\circ} \mathrm{C}-10 \mathrm{hrs}$ & 25.52 & -84 \\
$50^{\circ} \mathrm{C}-10 \mathrm{hrs}$ & 20.54 & -91 \\
$50^{\circ} \mathrm{C}-12 \mathrm{hrs}$ & 7.4 & -1.4 \\
$60^{\circ} \mathrm{C}-8 \mathrm{hrs}$ & 7.44 & -8 \\
$60^{\circ} \mathrm{C}-10 \mathrm{hrs}$ & 3.86 & -3.3 \\
$60^{\circ} \mathrm{C}-11 \mathrm{hrs}$ & 5.68 & -3.28 \\
\hline
\end{tabular}

The computed effective moisture diffusivity $\left(\mathrm{D}_{\text {eff }}\right)$ of ogi is as shown in Table 2. These values were comparable with values obtained from some researchers (Babalis and Belessiotis, 2004; Aghbashlo et al., 2009; Mirzaee et al., 2009). Research reports indicated possible factors like drying conditions, experimental procedures, data treatment methods, temperature, product properties, compositions, physiological state and heterogeneity of structure may affect effective moisture diffusivity during dehydration (Babalis and Belessiotis, 2004; Aghbashlo et al., 2009; Mirzaee et al., 2009). The fineness of ogi and its closely packed structure may have affected the entire drying kinetics and effective moisture diffusivity as well.

\subsection{Volatile compound}

The average retention time for respective detected volatile compounds of ogi produced from maize grains at designed experimental condition (drying temperature and drying time are as shown in Table 3 . The volatile compounds of ogi before drying and dried maize grains were as well included. A total of thirty-five volatile compounds were detected in wet ogi, dried ogi and dried maize grains. The retention time ranged from 9.67 to 26.96 mins. There was no significant difference $(p<0.05)$ in the retention time of the same volatile compounds across the experimental condition for wet and dried ogi as well as dried maize grain. The acetaldehyde found in fresh ogi, dried ogi and dried maize grain recorded retention time ranging from 9.69-9.86 mins while the last detected volatile compound, ethyl caprate retention time for wet ogi, dried ogi and dried maize grain range between 25.05-26.67 mins. The number of these volatile compounds were lower than values reported for fermented dough and yoghurt, respectively (Annan et al., 2003; Cheng, 2010).

The acetaldehyde, ethyl butyrate, 2-methyl butanol, ethanol, hexanal, isoamyl acetate, 2,3-butanediol, propanoic acid, ethyl caproate, 2,3-butanedione, 3methyl butanol, 2-methyl propanol, heptanol, acetic acid, propyl acetate and propanol reduced by $99.99 \%$ while nonanal reduced by $99.88 \%$, hexadecenoic acid by $97.93 \%$, ethyl acetate by $97.25 \%, 2$-methyl-naphthalene by $95.02 \%$, E-2-nonenal by $96.62 \%$, 2-methoxyphenol by $60.43 \%$, ethyl dec-9-enoate by $87.38 \%$ and ethyl lactate by $10.36 \%$. This was consistent with the reports from some researchers (Baranauskiene et al., 2006; Calin -Sanchez et al., 2011; Huang et al., 2016). The losses recorded in this work were higher than values reported by these researchers. However, isobutyl acetate, imethylnaphthalene, ethyl isovalerate, ethyl caprylate, ethyl valerate 2-Nonenal and 2-methoxy-4-vinylphenol increased in dried ogi and dried maize grains when compared with these volatile compounds in wet ogi. The concentration of respective volatile compounds in dried ogi compared with respective concentration in wet ogi is as shown in Figure 2. These losses of the volatile compounds may have contributed to the observation of usual deviation in aroma and flavour of dried ogi from fresh ogi slurry in earlier research works (Bolaji, Oyewo and Adepoju, 2014, Bolaji et al., 2015). The contor response surface model plot in Figure 3 revealed that all 








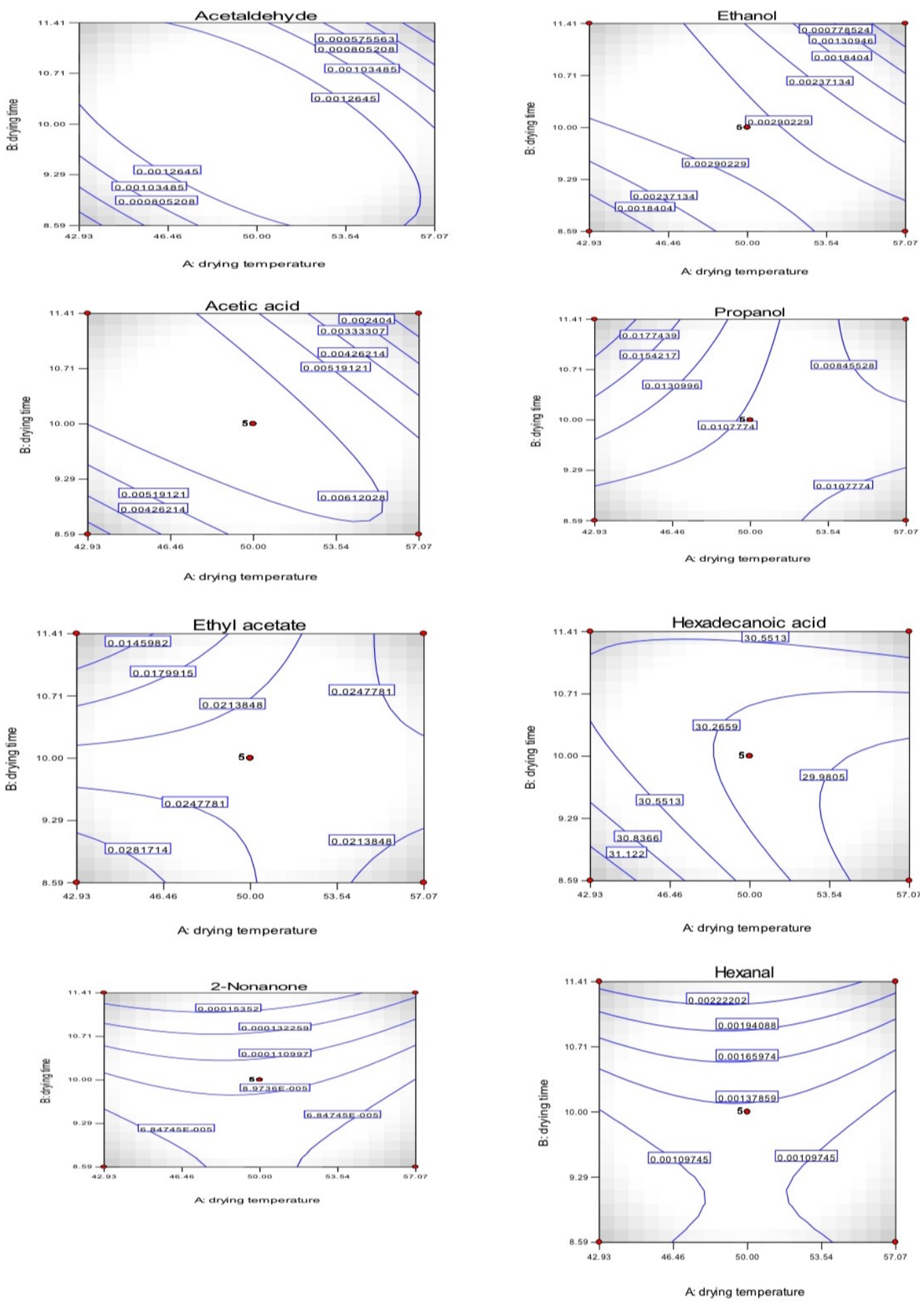

Figure 3. Contour plot of some volatile compounds' reduction at varying drying condition of temperature and time when compared with fresh ogi product

the volatile compounds decreased with increased drying temperature and time. According to Azime et al. (2018), the drying techniques and condition in this research work may have encouraged the losses of volatile compounds. According to Huang et al. (2016), the lower drying temperature may be advantageous. The results obtained for some volatile compounds showed that they were thermally unstable. Unlike the report by Toontom et al. (2016), there were no outright disappearances of some volatile compounds detected during and after drying in this work, but the gross reduction was evidently recorded. The increase in acetic acid after drying for Thai chilli's operation reported by Toontom et al. (2016) was completely contrary to the observation in this study.

The first principal component for dried ogi had a variance of eigenvalue $32.04 \%$ and account for $91.5 \%$ while the second principal component had a variance of 1.92 accounted for $5.70 \%$. The third and fourth principal components had variances 0.975 and 0.011 , (2.80 and $0.00 \%$ ), respectively. The principal components showed that few volatile compounds were relevant on the flavour and aroma of the dried ogi since some with higher per cent concentration detected in freshly produced ogi had grossly reduced by drying operation employed in this work. 


\section{Conclusion}

As expected, the drying rate of the operation decreased with increased drying time. About fourteen out of the thirty-five volatile compounds detected in the dried ogi and dried maize grains significantly $(\mathrm{p}<0.05)$ reduced up to $99.99 \%$ when compared with wet ogi. While nonanal, hexadecanoic acid, ethyl acetate, 2methyl-naphthalene, E-2-nonenal, 2-methoxlphenol, ethyl dec-9-enoate and ethyl lactate reduced by $99.88 \%$, $97.93 \%, 97.25 \%, 95.02 \%, 96.62 \%, 60.43 \%, 87.38 \%$ and $10.36 \%$ respectively. The concentration of respective volatile compounds in dried ogi compared with respective concentration in wet ogi suggested the loss of aroma and flavour. This work established that some of the volatile compounds detected in this work were thermally unstable. In order to retain the volatile compounds in ogi during drying operation, there may be a need to develop an improved or employ drying process capable of reducing the losses of relevant volatile compounds experienced in this work.

\section{Conflict of Interest}

The authors declare no conflict of interest.

\section{Acknowledgement}

This work was supported by the Tertiary Education Trust Fund-Nigeria (TETFund). The authors gratefully acknowledge the provision of the fund to conduct this research.

\section{References}

Annan, N.T., Poll, S., Sefa-Dedeh, L., Plahar W.A. and Jakobsen, M. (2003). Volatile compounds produced by Lactobacillus fermentum, Saccharomyces cerevisiae and Candida krusei in single starter culture fermentations of Ghanaian maize dough. Journal of Applied Microbiology, 94(3), 462-474. https://doi.org/10.1046/j.1365-2672.2003.01852.x

AOAC. (1990). Official methods of analysis. $15^{\text {th }}$ ed. Washington, DC: Association of Official Analytical Chemists.

Azime, Ö., Gülşah, Ö. and Ömer, U.Ç. (2018). Effects of drying methods on the composition of volatile compounds in fruits and vegetables. In Siegmund, B. and Leitner, E. (Eds.). Flavour science., p. 95-98. Austria: Verlag der Technischen Universität Graz.

Aghbashlo, M., Kianmehr, M.H. and SamimiAkhijahani, H. (2009). Evaluation of thin-layer drying models for describing drying kinetics of barberries (Barberries vulgaris). Journal of Food Process Engineering, 32(2), 278-293. https:// doi.org/10.1111/j.1745-4530.2007.00216.x
Babalis, S.J. and Belessiotis, V.G. (2004). Influence of drying conditions on the drying constants and moisture diffusivity during the thin-layer drying of figs. Journal of Food Engineering, 65(3), 449-458. https://doi.org/10.1016/j.jfoodeng.2004.02.005

Baranauskiene, R., Venskutonis, P.R., Dewettinck, K. and Verhé, R. (2006). Properties of oregano (Origanum vulgare L.), citronella (Cymbopogon nardus G.) and marjoram (Majorana hortensis L.) flavors encapsulated into milk protein-based matrices. Food Research International, 39(4), 413425. https://doi.org/10.1016/j.foodres.2005.09.005

Bolaji, O., Olalusi, A.P. and Adesina, B.S. (2015). Mathematical Modeling of Drying Pattern of $O g i$ Produced from Two Types of Maize Grain. Journal of Food Research, 4(1), 174-185. https:// doi.org/10.5539/jfr.v4n1p174

Bolaji, O.T., Abegunde, T.A, Praise-Ofuani-Oyinloye, O.C, Fashakin, J.F. and Apotiola, Z.O. (2017). Impact of Soaking Period and Drying Temperature on the Pasting Properties of Ogi Produced from Some Selected Maize Varieties American Journal of Food Science and Technology, 5(5), 220-227. https:// doi.org/10.12691/ajfst-5-5-8

Bolaji, O.T., Oyewo, A.O, and Adepoju, P.A (2014). Soaking and Drying Effect on the Functional Properties of Ogi Produce from Some Selected Maize Varieties. American Journal of Food Science and Technology, 2(5), 150-157. https:// doi.org/10.12691/ajfst-2-5-3

Bolaji, O.T. Adenuga-Ogunji, L. and. Abegunde, T.A. (2017). Optimization of processing condition of ogi produced from maize using response surface methodology (RSM). Cogent Food and Agriculture, 3(1), 1-10. https:// doi.org/10.1080/23311932.2017.1407279

Bolaji, O.T. Akindele, A.D. and Aina, O.D. (2014). Mathematical modelling of Drying pattern and thermal properties of ogi produced from four maize varieties Annals. Food Science and Technology, 15 (2), 210-216.

Calin-Sanchez, A., Szumny, A. Figiel, A., Jałoszyński, K., Adamski, M. and Carbonell-Barrachina, Á.A. (2011). Effects of vacuum level and microwave power on rosemary volatile composition during vacuum-microwave drying. Journal of Food Engineering, 103(2), 219-227. https:// doi.org/10.1016/j.jfoodeng.2010.10.018

Cheng, H. (2010). Volatile Flavor Compounds in Yogurt: A Review. Critical Reviews in Food Science and Nutrition, 50(10), 938-950. https:// doi.org/10.1080/10408390903044081 
Díaz-Maroto, M.C., Pérez-Coello, M.S., Vinas, M.A.G. and Cabezudo, M.D. (2003). Influence of drying on the flavor quality of spearmint (Mentha spicata L.). Journal of Agriculture and Food Chemistry, 51(5), 1265-1269. https://doi.org/10.1021/jf0208051

Perea-Flores, M.J., Garibay-Febles, V., Chanona-Perez, J.J., Calderon-Domingues, G., Mendez-Mendez, J.V., Palacios, Gonzalez, E. and Guiterrez-Lopez, G.F. (2012). Mathematical modelling of castor oil seeds (Ricinus Communis) drying kinetics in fluidized bed at high temperatures. Industrial Crops and Products, 38, 64-71. https://doi.org/10.1016/ j.indcrop.2012.01.008

Huang, Q., Chen, L., Song, H., An, F., Teng, H. and Xu, M. (2016) Effect of Different Drying Method on Volatile Flavor Compounds of Lactarius deliciosus Qun. Journal Food Process and Technology, 7, 8. https://doi.org/10.4172/2157-7110.1000615

Hawlader, M.N., Perera, C.O. and Tian, M. (2006). Properties of modified atmosphere heat pump dried foods. Journal of Food Engineering, 74(3), 392-401. https://doi.org/10.1016/j.jfoodeng.2005.03.028

Hadrich, B., Boudhrioua, N. and Kechaou, N. (2008.) Drying of Tunisian sardine (Sardinella aurita): experimental study and three-dimensional transfer modelling of drying kinetics. Journal of Food Engineering, 84(1), 92-100. https://doi.org/10.1016/ j.jfoodeng.2007.04.025

Mirzaee, E, Rafiee1, S, Keyhani1, A. and EmamDjomeh, Z. (2009). Determining of moisture diffusivity and activation energy in drying of apricots, Research in Agricultural Engineering, 55 (3), 114-120. https://doi.org/10.17221/8/2009-RAE

Moraga, G., Martinez-Navarrete, N. and Chiralt, A. (2004). Water sorption isotherms and glass transition in strawberries: influence of pre-treatment. Journal of Food Engineering, 6, 315-321. https:// doi.org/10.1016/S0260-8774(03)00245-0

Shi, Q.-L., Chang-Hu, X., Ya, Z., Zhao-Jie, L. and Xiang -You, W. (2008). Drying characteristics of horse mackerel (Trachurus japonicus) dried in a heat pump dehumidifier Journal of Food Engineering, 84(1), 12 -20. https://doi.org/10.1016/j.jfoodeng.2007.04.012

Toontom, N., Posri, W., Lertsiri, S. and Meenune, M. (2016). Effect of drying methods on Thai dried chilli's hotness and pungent odour characteristics and consumer liking. International Food Research Journal, 23(1), 289-299

Zielinska, M. and Michalska, A. (2016). Microwaveassisted drying of blueberry (Vaccinium corymbosum L.) fruits: Drying kinetics, polyphenols, anthocyanins, antioxidant capacity, colour and texture. Food Chemistry, 212, 671-680. https:// doi.org/10.1016/j.foodchem.2016.06.003 